\author{
А.С. Асилова ${ }^{1}$ (D), А.К. Тусаева ${ }^{2}$, Г.Е. Касенова ${ }^{1}$ \\ 'Әл-Фараби атындағы Қазақ ұлттық университеті, \\ Қазақстан, Алматы қ., e-mail: aijan1910@gmail.com \\ ${ }^{2}$ Еуразиялық технологиялық университеті, Қазақстан, Алматы қ.,
}

\title{
ИНВЕСТИЦИЯАЫК ПОРТФЕАЬАІ
} БАСКАРУ ТИІМАІАІГІН БАҒАААУ

Бұл мақалада пайдаланылатын инвестициялық портфельді таңдау және басқару саласындағы маңызды мәселелер қарастырылады. Кірістіліктің белгіленген деңгейіне қол жеткізу және тәуекел деңгейін азайту мақсатында белгілі экономистердің негізгі принциптері, инвестициялау ережелері ұсынылған. Қаржылық инвестициялар портфелін басқару тиімділігін бағалауға мүмкіндік беретін түрлі коэффициенттер қарастырылады. Табыстылық пен тәуекел кез келген инвестицияларды, оның ішінде инвестициялық, портфельді бағалау үшін негізгі параметрлер болып табылатындығы аталып өтілді. Әрқашан тәуекел мен табыстылық арасында мәміле бар, сондықтан активтердің үйлесімі портфель сапасына әсер етеді. Сонымен қатар инвестициялық портфельді талдау және оңтайландыру мәселелері қарастырылады. Сондай-ақ, портфолио негізін қалаушы Гарри Марковиц және оның селективті моделі та^данды. Портфельдің тәуекелін және кірістілігін бағалауға және олардың корреляциясы мен ковариациясын есептеуге арналған. Та^данатын коэффициенттер арасында - Шарп коэффициенті, Сортино коэффициенті, омега коэффициенті, бета коэффициенті, а^ьфа коэффициенті, VaR коэффицциенті және басқалар. Қандай да бір коэффициентті қолданудың артықшылықтары анықта^ды. Зерттеудің нәтижесі әрбір коэффициентті қолдануда портфель туралы өз ақпаратын алып, оларды кешенді түрде қарастыру қажет екендігі атап өтілді. Инвестициялық портфельдің тиімділігін арттыруда индекстік қорларға инвестициялаудың маңыздылығы белгілі болды. Қарастырылған коэффициенттерден басқа, инвестордың жеке мақсаттарына, сондай-ақ қорлар қызметінің өзге де көрсеткіштеріне назар аудару қажет. Әлемдегі тәуелсіз инвестициялық қорлар бүгінгі күні тәуекелдерді бағалау мен өзінің инвестициялық портфельдерін қалыптастыруға әртүрлі тәсілдерді қолданады біреуі өз қаражатын неғұрлым тәуекел активтерінің пайдасына бөлсе, басқалары консервативті стратегияларды ұстанады. Мұндай қорлардың қаражатын басқару мұқият ойластырылған инвестициялық стратегияға негізделуі тиіс. Зерттеудің нәтижелері инвестициялық портфельді дұрыс қалыптастыру мен тиімді басқару аясында пайдаланылады.

Түйін сөздер: қаржылық инвестициялар, инвестициялық портфель, Шарп коэффициенті, Сортино коэффициенті, омега коэффициенті.

\author{
A.S. Assilova ${ }^{1}$, A.K. Tussayeva², G.E. Kassenova ${ }^{1}$ \\ 'Al-Farabi Kazakh National University, Kazakhstan, Almaty, e-mail: aijan1910@gmail.com \\ ${ }^{2}$ Eurasian Technological University, Kazakhstan, Almaty
}

\section{Assessment of efficiency of investment portfolio management}

This article discusses the important issues in the selection and management of the investment portfolio, which are used. In order to achieve the established level of profitability and reduce the level of risk, the basic principles of well-known economists and investment rules are presented. Discusses the various factors used to evaluate the effectiveness of portfolio management of financial investments. It was noted that profitability and risk are the main parameters for the evaluation of any investment, including the investment portfolio. There is always a trade between risk and return. Therefore, the combination of assets affects the quality of the portfolio. The selective model of G. Markowitz, who is the founder of the portfolio, is also analyzed. The model is designed to assess the risk and return of the portfolio and calculate their correlation and covariance.Among the analyzed factors-the coefficient of the square, Sortino ratio, omega ratio, beta coefficient, coefficient alpha, coefficient of $\mathrm{VaR}$ and others. Advantages of application of any coefficient were defined. It was stressed that the results of the study needed to be informed about the portfolio using each factor and considered in an integrated manner. In improving the efficiency of the investment portfolio, the importance of investing in index funds was noted. In addition to the provided coefficients, it is necessary to pay attention to the investor's own goals, as well as to other indicators of 
the funds ' activities. Sovereign wealth funds in the world today use different approaches to risk assessment and the formation of their investment portfolios-one distributes its funds in favor of the most risky assets, others adhere to conservative strategies. The management of such funds should be based on a carefully considered investment strategy. The results of the research are used in the framework of the correct formation of the investment portfolio and management.

Key words: financial investments, investment portfolio, Sharp coefficient, Sortino coefficient, omega coefficient.

\section{А.С. Асилова' ${ }^{1}$ А.К. Тусаева², Г.Е. Касенова ${ }^{1}$}

1'Казахский национальный университет имени аль-Фараби, Казахстан, г. А^маты, e-mail: aijan1910@gmail.com Еразийский Технологический Университет, Казахстан, г. Алматы

\section{Оценка эфффективности управления инвестиционным портфелем}

В Аанной статье рассматриваются важные вопросы, возникающие при отборе и управлении инвестиционным портфелем. А^я достижения установленного уровня доходности и снижения уровня риска представлены основные принципы известных экономистов и правила инвестирования. Рассматриваются различные факторы, используемые Аля оценки эффективности управления портфелем финансовых инвестиций. Было отмечено, что АохоАность и риск являются основными параметрами оценки ^юбых инвестиций, в том числе инвестиционного портфеля. ВсегАа есть взаимосвязь между риском и доходностью. Поэтому сочетание активов влияет на качество портфеля. Рассмотрены вопросы анализа и оптимизации инвестиционного портфеля. Также анализируется селективная модель Г. Марковица, который является основателем портфолио. Модель предназначен Аля оценки риска и доходности портфеля и расчета их корреляции и ковариации. Среди анализируемых факторов - коэффициент Шарпа, коэффициент Сортино, коэффициент омега, коэффициент бета, коэффициент А^ьфа, коэффициент Var и другие. Определены преимущества применения ^юбого коэффициента. Было подчеркнуто, что в результатах исследования необходимо информировать о портфеле с использованием каждого фактора и рассматривать на комплексной основе. При повышении эффективности инвестиционного портфеля отмечена важность инвестирования в индексные фонды. Помимо предоставленных коэффициентов, необходимо обратить внимание на собственные цели инвестора, а также на другие показатели деятельности фондов. Суверенные инвестиционные фонды в мире на сегодняшний день используют различные подходы к оценке рисков и формированию своих инвестиционных портфелей - одни распределяют свои среАства в пользу наиболее рисковых активов, Аругие придерживаются консервативных стратегий. Управление средствами таких фондов Аолжно основываться на тщательно продуманной инвестиционной стратегии. Результаты исследования используются в рамках правильного формирования и управления инвестиционного портфеля.

Ключевые слова: финансовые инвестиции, инвестиционный портфель, коэффициент Шарпа, коэффициент Сортино, коэффициент омега.

\section{Kipicne}

Қазіргі уақытта қаржы нарығы капиталды инвестициялаудың көптеген мүмкіндіктерін ұсынады және бұл инвестициялаудағы маңызды аспект - дұрыс қалыптасқан инвестициялық портфель. Нарықтық экономика жағдайында инвестициялық портфельді ұтымды қалыптастыру инвесторға табыс алуға және өзінің болашағын әл-ауқатты арттыруға мүмкіндік береді. Инвестициялық портфельді қалыптастырумен жеке және институционалдық инвесторлар айналысатыны құпия емес. Экономикадағы бүгінгі өзгерістер әлемдік қаржы нарығында әртүрлі салдарға әкеп соқтырады. Батыс әлемінде инвестициялаудың негізгі қаржы құралдарына әртүрлі бағалы қағаздарға және хедж-қорларға, инвес- тициялық қорларға салынатын салымдар жатады. Инвестициялық қорлар тұлғалар мен компаниялар үшін қаржы ресурстарын жинайтын және оларды бағалы қағаздардың әртараптандырылған портфеліне инвестициялайтын қаржы делдалдары болып табылады (Buc, 2013). Екінші деңгейдегі банктер, зейнетақы қорлары және инвестициялық қорлар атынан ұсынылған институционалдық инвесторлар іргелі және техникалық талдаулар есебінен қаржы нарығының активтеріне инвестициялайды. Орта және ұзақ мерзімді инвестициялау үшін іргелі талдаудың техникалық талдау алдында артықшылықтары бар. Өйткені іргелі сипаттамалардың көмегімен компанияның нарықтағы болашақ дамуын бағалауға болады. Техникалық талдау трейдерлер арасында және қысқа уақыт аралығында инвесторлар арасында 
өте танымал. Қор нарығындағы инвестициялық портфельдерді бағалау үшін әр түрлі тиімділік коэффициенттері пайдаланылады. Оларды екі топқа бөлуге болады: бұл инвестициялардың абсолютті және салыстырмалы тиімділік көрсеткіштері. Мәселен, инвестициялық портфель тиімділігінің абсолюттік көрсеткіштері тәуекел мен кірістіліктің негізгі көрсеткіштерінің абсолюттік өзгерістерін көрсетеді. Салыстырмалы коэффициенттер тиісінше салыстырмалы өзгерісті көрсетеді. Инвестициялық талдауда кірістілік пен тәуекел кез келген инвестицияларды бағалау үшін негізгі параметрлер болып табылады. Инвестицияның тиімділігін бағалаудың мақсаты қор нарығындағы басқарудың табысты және нәтижелі стратегияларын анықтау болып табылады, олар тәуекелдің ең төменгі деңгейінде орташа нарықтық деңгейден жоғары кірістілікті алуға мүмкіндік береді. Бұл көрсеткіштер портфельдерді басқару нәтижелері арасында саралау және салыстыру үшін пайдаланылады. Белгілі бір коэффициенттер негізінде қолданылатын стратегияны пайдалану және оның модификациялары туралы одан әрі шешімдер қабылданады.

\section{Әдіснама}

Мақалада жүйелік, факторлық және динамикалық талдау әдістері, ғылыми абстракциялар, жүйелік тәсілдер қолданылды. Осы проблематиканы зерттейтін авторлардың жұмыстарына қысқаша талдау жасалды.

Жүйелік талдау - бұл зерттелетін жүйенің ауыспалы немесе тұрақты элементтері арасындағы құрылымдық байланыстарды орнату бойынша іс-әрекеттердің бірізділігін білдіретін танымның ғылыми әдісі.

Факторлық талдау - бұл кешенді және жүйелі зерттеу және нәтижелі көрсеткіш шамасына факторлардың әсерін өлшеу әдістемесі. Бұл мақалада инвестициялық портфель және инвесторлардың табыс мөлшері сияқты капитал өсімінің көлеміне әсер ететін негізгі факторлар қарастырылған.

Динамикалық талдау - экономикалық талдау әдісі, оның көмегімен бір тепе-тең жағдай басқасына ауысатынын көруге болады.

Ғылыми абстракция әдісі - экономикалық теорияның әдісі, ол экономика субъектілері арасындағы жекелеген елеусіз өзара қарым-қатынасты қараудан алып тастауға және бірнеше субъектілерге назар аударуға мүмкіндік береді.
Экономикадағы жүйелі тәсіл - ғылыми зерттеудің әдіснамалық бағыты, ол жүйелік талдау мен синтез тұрғысынан біртұтас экономика ретінде кешенді зерделеуден тұрады. Мұнда инвестициялық портфельді оңтайландыру мен әлемде пайдаланылатын тиімді тәсілдер қарастырылады.

\section{Әдебиеттерге шолу}

Мақалада инвестиция және инвестициялық портфельдерді тиімді бағалау саласындағы ғалым-экономистердің еңбектері зерделенді және қорытындыланды.

Инвестициялық портфельді құру мен басқару әдістерінің спектрі өте үлкен. Ресейлік К. Нечаев, А. Зыбин экономистерінің зерттеулерінде У. Шарптың инвестициялық портфелінің теориясы, Г. Марковиц пен Дж. Тобин коэффициенттерінің қазіргі заманауи портфель теориясын қалыптастырудағы маңызы мен негізгі принциптері қарастырылған. Ең төменгі тәуекелге ие болу үшін портфельді таңдауда Марковицтің орташа дисперсияға негізделген математикалық моделі ұсынылады. Активтер тәуекелі жекелей емес бірыңғай портфельдің тәуекелі ретінде қарастырылуы тиіс. Бұл саладағы білім деңгейі Н. Gaudecker, P. Burrough сияқты шетелдік академиялық экономистердің жұмыстарында оның іргелі аспектілерін сипаттаумен анықталады. G. Nick зерттеуіне сәйкес, портфель активтерінің табыстылықтары арасындағы корреляциялық байланыстардың есебін қалыптастыру керек. Бір белгіге негізделген инвестициялық сипаттамалар портфелін есептеу әдістерін, портфельдің тиімділігін бағалау бойынша экономист Э. Роббинс Далионың инвестициялау принциптері өте тиімді, қарапайым және мұндай портфельдерді кез келген инвестор құра алатындығы айқындалған.

\section{Нәтижелер және талқылау}

Жеке инвесторлар болашақта пайда табу мақсатында қаржы нарығына инвестиция салады. Жеке инвестордың сипаттамасы инвестициялау объектілерін анықтау алдында бірінші кезекте инвестордың типі, яғни оның тәуекелге орналасуы бағаланады. Егер инвестордың тәуекелге орналасуы жоғары болса, онда бұл инвестор агрессивті инвестор болып табылады. Агрессивті инвестордың мақсаты - сатып алу және сату бағасының айырмасының есебінен пайда алу мақсатында қаржы құралдарына 
инвестиция сала отырып, барынша жоғары пайда алу. Орташа агрессивті инвестордың агрессивті инвесторға қарағанда тәуекелі аз дәрежеде болады. Орташа агрессивті инвестор акциялар бойынша дивидендтер және облигациялар бойынша купондық төлемдер түрінде ұсынылған қаржы құралдары бағасының және ағымдағы кіріс айырмасының есебінен пайда ала алады. Консервативті инвестор өз қаржыларын тәуекелі аз активтерге, мысалы ipi компаниялардың акцияларына, рейтингі жақсы корпоративтік облигацияларға және мемлекеттік бағалы қағаздарға бөледі. Қаржы нарығында инвестордың әрбірі өзінің таңдауы бойынша инвестициялау объектісін таба алатынымен, яғни инвестордың тәуекел дәрежесіне байланысты әр түрлі. Дамыған елдерде бағалы қағаздардың танымалдығы осы құралдардан жақсы табыстылыққа негізделген. Бұл көрсеткіш депозит бойынша ставкалармен салыстырғанда жоғары, алайда тәуекел дәрежесі жоғары болады (Нечаев, 2014).

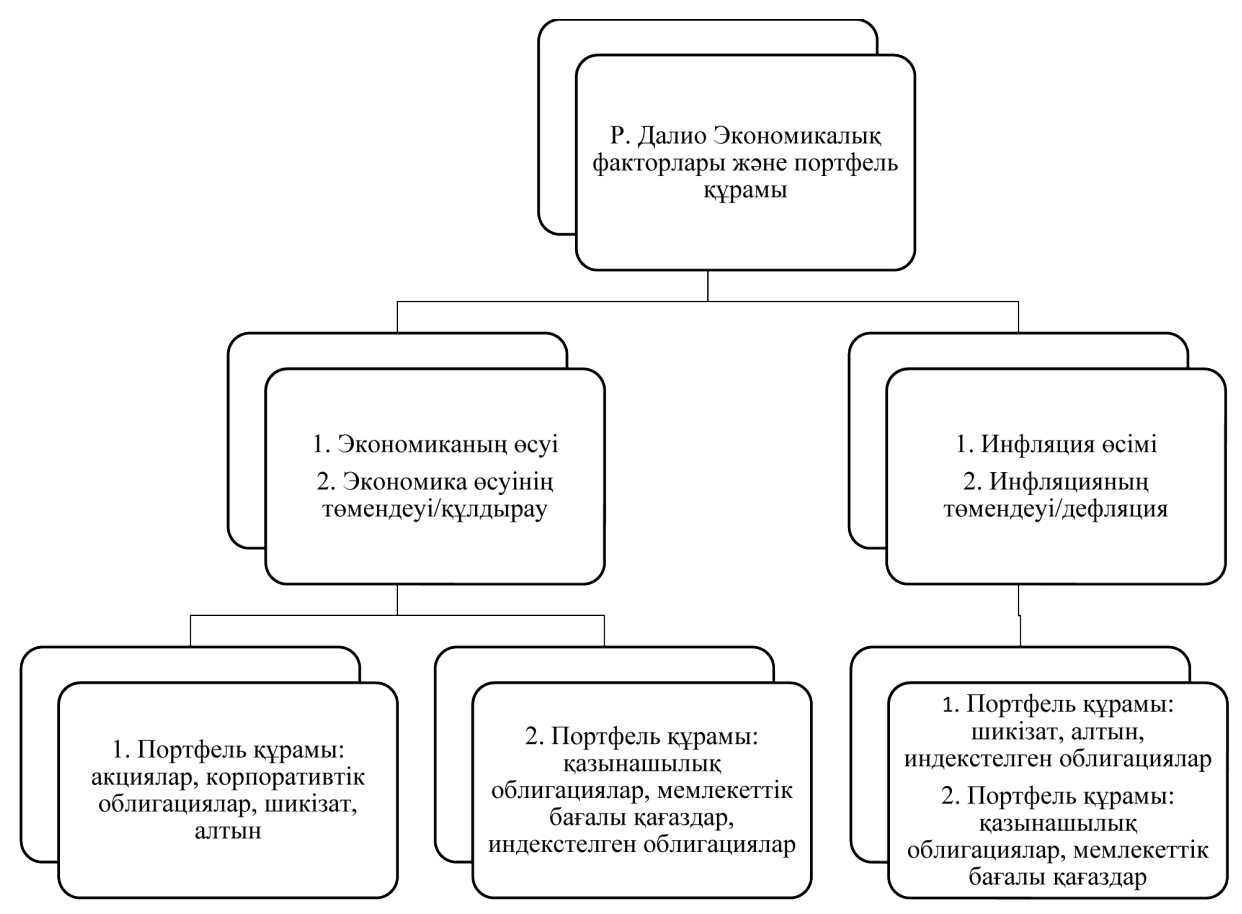

1-сурет - Р. Далио қағидалары бойынша портфель құрамы

Ескерту - (Роббинс, 2015: 330) дерегі негізінде құрастырылған

Уоррен Баффетт сияқты тәжірибелі инвестор негізгі принциптерді, инвестициялау ережелерін ұсынады, олардың көмегімен біз кірістіліктің белгіленген деңгейіне қол жеткізе аламыз және тәуекел деңгейін азайтып, алдын ала аламыз. Осы инвесторларға жыл сайын өз табысын арттыруға қандай қағидаттар көмектеседі деген сұрақ туындайды.

Қазіргікезеңдепортфельдікинвестициялауға көп көңіл бөлінуде. Портфельдік инвестициялау теориясына Нобель сыйлығының лауреаты Гарри Марковиц салмақты үлес қосты. Барлық ұсынылған модельдер тәуекел мен кірістілік арақатынасына негізделеді. Ғалым сенімді бағалы қағаздар жоқ екенін дәлелдеді, олардың барлығы тәуекелмен байланысты. Бұл ғалым бағалы қағаздар портфелінің теориясын екі бөлікке бөлді - акциялар активтері үшін жүйелі тәуекел және жүйесіз тәуекел. Акциялар үшін жүйелі тәуекел әрдайым нарықта айналыстағы бағалы қағаздар құнының өзгеруіне, яғни бағалы қағаздардың барлық активінің орташа кірістілігінің айналасына байланысты. Сондықтан қаржы менеджерінің міндеті тәуекелді төмендету мақсатында түрлі бағалы қағаздарды сатып алуды ескере отырып, портфель қалыптастыру болып табылады. Бағалы қағаздар портфелі бір инвесторға тиесілі қаржы құралдарының жиынтығы болып табылады. Инвестициялау қағидаты бірінші кезекте активтердің құрылымын және оның сипаттамасын анықтауды көздейді. Марковиц актив- 
терге инвестициялау жеке емес, жиынтыққа негізделуі тиіс деп айтылған теорияны әзірледі. Әрқашан тәуекел мен табыстылық арасында мәміле бар. Сондықтан активтердің үйлесімі портфель сапасына әсер етеді.

Рэй Далио - Bridgewater хедж қорының иесі. Оның қоры әлемдегі ең ірі қор болып саналады, оның басқаруында 160 млрд доллар сомасында активтері бар. Көптеген инвесторлар тәуекелдерді азайту үшін 50\% акцияларға және 50\% облигацияларға салым жасау қажет деп санайды. Алайда қаржыгер Р. Далио бұл салымда акциялардың үлесіне тәуекелдің 95\%-ы тиесілі екенін көрсетеді. Бұл тұжырым, тәуе- келдердің төмендемегенін көрсетеді және портфель тәуекелдің жоғары ықтималдығына ие. Сондықтан активтерге ақшаны бөлу активтердің құны бойынша емес, тәуекел/кіріс арақатынасы бойынша болуы тиіс. Бұл қағидаттан басқа, Далио активтердің бағасына әсер ететін 4 факторды анықтады - инфляция, дефляция, экономиканың өсуі, экономика өсуінің баяулауы немесе құлдырауы. Бұл факторларға активтер кірістілігінің артуы немесе төмендеуі жатады. Далио стратегиясы бүкіл маусымдық болып табылады, өйткені портфель барлық экономикалық факторлардың әсерін ескереді (жылдың төрт мезгілін пайдалану) (1-сурет).

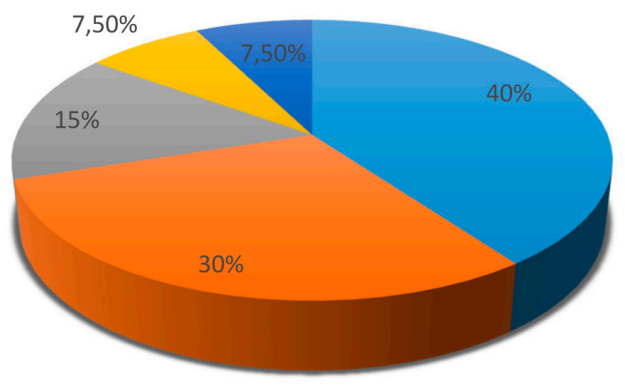

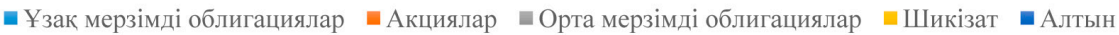

2-сурет - Р. Далио қағидаларына сәйкес портфель құрылымы Ескерту - (Роббинс, 2015:330) дерегі негізінде құрастырылған

Келесі кезең - берілген параметрлер бойынша портфелді құрылымдау. Берілген қағидат бойынша акция үлесіне 30\% келуі тиіс, ал ең үлкен үлеске (40\%) ұзақ мерзімді облигацияларға инвестициялау қажет. Ұзақ мерзімді облигациялардың уақытына қатысты айналым мерзімі 20 жылдан 25 жылға дейінгі, ал орта мерзімді облигацияларға - 7 жылдан 10 жылға дейінгі облигациялар жатады. Шикізат пен алтынның үлесіне барлық портфельдің 15\%-ы келеді, олардың әрқайсысы бірдей үлеске ие $(7,5 \%)$.

Облигациялар бойынша елеулі салмақ себебі неде? Бізге белгілі болғандай, акциялар облигацияларға қарағанда аса қауіпті, өйткені олар бойынша құбылмалылық облигацияларға қарағанда жоғары. Құбылмалылық акция курсының өзгеруін білдіреді. Сондықтан облигациялардың едәуір үлесі акциялардың құбылмалылығын жабады. Сондай-ақ, экономика мен инфляцияның өсуі кезінде шикізат пен алтынның құнында өсетінін есте сақтау қажет. Сондықтан осы факторларды ескере отырып, аталған активтерге инвестиция салуға болады. Біздің ойымызша, шикізат пен алтынға инвестиция салу тура мағынада түсіндірілмеуі тиіс. Шикізатқа, алтынға және басқа активтерге инвестициялауға болатын түрлі қаржы құралдары бар. Бұлар - фьючерстер, опциондар сияқты туынды құралдар (деривативтер). Фьючерстік және опциондық келісімшарттар болашаққа арналған келісім-шарттар болып табылады. Сіз осы құралдарды инвестициялайсыз және активтерді дұрыс болжаған кезде пайда табасыз (бұл жағдайда шикізат пен алтын). Активтердің арақатынасы әрдайым сақталуы тиіс, сондықтан портфельдің қайта балансталуын жүргізу қажеттілігі бар. Сіз барлық активтерге 100 млн теңге инвестицияладыңыз. Р. Далио принципін басшылыққа ала отырып, сіз акцияларға - 30 млн теңге, ұзақ мерзімді активтерге 40 млн теңге, орта мерзімді облигацияларға 15 млн теңге және шикізат пен алтынға 15 млн 
теңге салдыңыз. Белгілі бір уақыттан кейін сіз акцияларға салынған ақша бағада артып, 33 млн теңгені құрайтынын бағалайсыз. Орта мерзімді облигациялардың құны төмендеді және 14 млн теңгені құрады, алайда ұзақ мерзімді облигациялар бойынша құны 2 млн теңгеге өсті, бұл 42 млн теңгені құрады. Оңайлатылған есептеу үшін шикізат пен алтын бағасы бұрынғы деңгейде қалғанын болжаймыз. Активтерді ұлғайту мен азайту кезінде портфель құрылымы өзгерді. Акция үлесіне 31,7\% келеді, бұл рұқсат етілген деңгейден 1,7\% жоғары. Қалған активтер бойынша мұндай жағдайда қайта баланстау үшін асып кеткен активтердің бір бөлігін сату және азайған жерде қосымша сатып алу қажет. Осындай операциялардың көмегімен біз активтердің қажетті пропорциясына қол жеткіземіз. Уоррен Баффет бізге тәжірибелі инвестор және «Berkshire Hathaway» қаржы компаниясының иесі ретінде белгілі. У. Баффет нарықтағы табыс уақытша кезеңмен тығыз байланысты екенін дәлелдейді. Инвестициялаудың ұзақ мерзімді кезеңін инвестор таңдаған сайын, ол болашақта табысқа жету ықтималдығы соғұрлым жоғары болады. У. Баффет теориялары (принциптері) әртараптандырудың белгілі теориясына қайшы келеді. Артық әртараптандыру шын мәніндепортфель тәуекелін арттырады, ал бірнеше бағалы қағаздарға шоғырлану, керісінше, тәуекелдің төмендеуіне және портфель кірістілігінің артуына алып келеді. Бірнеше компанияның саналы таңдауы инвесторға олардың қызметін мұқият зерделеуге, олардың нақты құнын анықтауға мүмкіндік береді. Белгілі миллионер мен «Berkshire Hathaway» компаниясы басшысының басты ұстанымы бағаланбаған акцияларды іздеу және оларды сатып алу. Тәжірибе бізге жете бағаланбаған активтерге салынған ақша бағаның артуына алып келгенін дәлелдейді, бұл салым кірістілігін арттырады. Бағаланбаған акциялар дегеніміз не? Бұл акциялар, олардың бағасы жоғары емес және оларға деген сұраныс айқын емес. Инвесторлар әрдайым Apple, Microsoft, Exxon mobile және т.б. сияқты танымал компаниялардың акцияларын көреді. Мысалы, Apple компаниясының нарықтық бағамы 95 долларды құрайды, бірақ бұл акцияның бухгалтерлік бағасы 23 доллардан (Khan, 2016) аспайды. Баффет принципіне сүйене отырып, компанияның тұрақты емес акцияларын іздеу керек, бірақ өсу әлеуеті бар болуы қажет, алайда, бұл тәсілде кемшіліктер бар. Ең алдымен бұл қаржы туралы білім қажет. Өйткені, бағаланбаған акцияларды анықтау үшін мұқият талдау жасай білу керек.
Сондықтан осы акцияларды анықтау үшін қаржы консультанттарына немесе брокерлерге жүгіну қажет. Қорыта келе, бұл тәсіл жеке компаниялар мен институционалдық инвесторлар үшін барынша қолайлы деп айта аламыз. У. Баффеттің келесі ережесі жеке инвесторларға арналған. У. Баффет принципі 10\% үлесі қысқа мерзімді мемлекеттік облигацияларға, ал қалған 90\%-ы индекстік қорларға салынуы тиіс. Индекстік қор ретінде гуру S\&P 500 индекс қорын ұсынады. Индекстік қор қалай жұмыс істейді? Жауап беру үшін бізге қор нарығындағы индекстің не екенін анықтауымыз қажет.

Қор индекстері қаржы әлемде бұрыннан қолданылып келеді. Бұл құралдың алғашқы түрі Доу Джонс индексі болып табылады. Екінші болып Standard and Poor's американдық компаниясы құрған S\&P индексі. Бастапқыда индекстің үлкен артықшылығы индекс құрамында сандық артықшылық болды. Егер Доу Джонс индексі 30 компания бойынша есептесе, онда S\&P өз құрамына экономиканың түрлі саласындағы 200 АҚШ компаниясын енгізді және сандық мөлшері 500 компанияға дейін жүзеге асырылды, бұл оның атауында қосымша әкелді (S\&P 500). Сандық сипаттама индекстің тиімділігіне әсер етті. Индекстік қор нарығы жағдайының көрсеткіші ретінде танымал және осы күнге дейін нарықты өлшеу өлшемі ретінде пайдаланылады. Индексті есептеу кезінде әрбір компанияның акцияларының құнын ескере отырып өлшенетін орташа өлшенген арифметикалық әдіс таңдалды. Компанияны индекстің құрамына енгізу үшін агенттік бірнеше шарттарды ұсынады. Біріншіден, бұл аумақтық тиістілік, яғни компания америкалық болуы керек. Екіншіден, компанияны капиталдандыруға қойылатын талаптар, бұл көрсеткіш 4 млрд доллардан артық болуы тиіс, сондай-ақ компания қаржылық тұрақты болуы тиіс. Үшіншіден, осы компания акцияларының кемінде 50\%-ы еркін айналыста болуы тиіс. Бұл жағдайда инвестор инвестицияның аумақтық бағытын анықтауы қажет. Егер артықшылық америкалық нарыққа берілсе, онда S\&P500, DJ және басқалар қор индекстері қолданылады. Басқа жағдайда еуропалық қаржы нарығына инвестициялау кезінде, бұл жағдайда СAC (Франция), FTSE (Ұлыбритания), DAX (Германия) қор индекстері аса танымал. Азия аймағында да танымал индекстер бар - Hang Seng (Гонконг) TOPIX, Nikkei (Жапония). Тиімді шешім қабылдау үшін бірнеше биржалық индекстердің жағдайы мен динамикасын салыстыру қажет. Өйткені индекстік 
қор нарығының жағдайын ғана емес, сондайақ экономикалық цикл фазасын көрсетеді. Экономикалық циклдің өсу фазасы инвестициялау тұрғысынан неғұрлым тартымды, өйткені макроэкономикалық көрсеткіштердің өсуімен қатар қор индекстері де жүреді.

S\&P 500 бірнеше себептер бойынша қор нарығында кеңінен қолданылады (қор нарығының индекстері S\&P 500, Website (2018)):

Эмитенттер санының көптігі. Бүгінгі күні осы сипаттама бойынша бір биржалық индекс осы көрсеткіштен аспайды. Индекске NYSE (389 компания) және Nasdaq (111 компания) қор биржаларында айналатын 500 ең ірі компания енгізілген.

Алдыңғы орынға Нью-Йорк қор биржасы ие. Белгілі индекс құрамына енгізілген компаниялардың салмағы индекстің жалпы үлесінің 78\%-ын құрайды. 90\%-дан аз акциялар NASDAQда хабарланатын компанияларға келеді. Индекс құрылымы экономиканың 8 секторы - шикізат, тұтыну тауарлары, қаржы секторы, денсаулық сақтау, индустриялық тауарлар, қызметтер, технологиялар, коммуналдық сектор арасында бөлінген. Барлық секторлар бойынша Нью-Йорк қор биржасы артықшылыққа ие. Алайда, технология секторы бойынша сурет кері көрнекілікке ие. Бұл жағдайда технологиялық компаниялар NASDAQ үлкен үлесін алады. Бұл таңқаларлық емес, өйткені NASDAQ технологиялық компаниялар биржасы деп аталады. Индекстің құрамы тұрақты сипатқа ие екенін атап өту қажет, яғни индекс құрамына енгізілген компаниялар кездейсоқ факторлар бойынша жоққа шығарылмайды.

Бүгінгі күні индекске америкалық экономиканың Apple, Chevron, Exxon Mobil, Johnson\& Johnson, Microsoft Corporation, Pfizer Inc сияқты ipi компаниялары енгізілген., The Procter \& Gamble Company, Wells Fargo \& Company, WalMart stores Inc. және басқа да капиталдандырумен 200 млрд доллардан астам компаниялар бар (Tussayeva, 2015: 36-42).

Индекстік инвестициялау тек қана индекстің құрылымы бойынша портфельді қалыптастыру есебінен ғана мүмкін емес. Инвестор өзара индекстік қорды таңдап, осы қордың пайын сатып ала алады. Индекстік қор - қор нарығының акциялары кіретін активтер жиынтығы. Инвестор осы қорға қаражат салады және ол индекстің өзінің өзгеруіне байланысты кіріс алады. Бұл құрал өте ыңғайлы және басқа инвестициялық қорлар сияқты тәуекелге ұшырамайды. Әрине, өзара қор қызметтері үшін инвестициялық та- быс жөніндегі комиссияларды алып тастайтын болады. Бірақ тәжірибе индекстік өзара қорлар инвесторға жоғары табыс әкелетінін дәлелдейді (Паук, 2014: 72-76).

Индекстік қорлардан бөлек, әлемдегі тәуелciз инвестициялық қорлар бүгінгі күні тәуекелдерді бағалау мен өзінің инвестициялық портфельдерін қалыптастыруға әртүрлі тәсілдерді қолданады - біреуі өз қаражатын неғұрлым тәуекел активтерінің пайдасына бөлсе, басқалары консервативті стратегияларды ұстанады.

Алайда активтерді тиімді басқару, бірінші кезекте, дәл осы ұзақ мерзімді мақсаттар мен міндеттерге қол жеткізуге бағдарлануы тиіс. Бұдан басқа, тәуелсіз қорлар активтердің елеулі бөлігін ұлттық байлық түрінде жинақтаумен байланысты, мұндай қорлардың қаражатын басқару мұқият ойластырылған инвестициялық стратегияға негізделуі тиіс.

Осыған байланысты, әлемдегі ең ірі егеменді инвестициялық қор - Норвегияның мұнай және мемлекеттік зейнетақы қоры 1 трлн доллар көлемінде - 2017 жылы инвестициялардың табыстылығын екі есе арттырды және 131 млрд доллар табыс тапты. Норвегияның мемлекеттік зейнетақы қорының қаражатын инвестициялау үшін рұқсат етілген активтер портфелі акциялар мен балама қаржы құралдарын қамтиды. Тұтастай алғанда Норвегиялық қордың инвестициялық саясатын қалыптастыру кезінде инвестициялық портфельдің активтер кластары, елдер, валюта құрамы және басқа да өлшемдер бойынша стратегиялық бөлінуі бекітіледі. Сонымен қатар, қаржы министрлігі халықаралық инвестициялық компаниялар есептейтін және жариялайтын қор индекстері түрінде ұсынылған бенчмаркингті белгілейді.

Норвегия азаматтарының қорды басқаруға деген кең ауқымды қоғамдық қолдауы мен сенімін қамтамасыз ету үшін қаржы министрлігі қордың инвестициялық стратегиясының маңызды аспектілері бойынша кең қоғамдық пікірталасқа жәрдемдесуге ұмтылады. Инвестициялық саясаттағы елеулі өзгерістердің жобалары ел Парламентінің Мәжілісіне ұсынылады. Сондықтан шешімдер қабылдаудың ашық процесі қордың инвестициялық стратегиясының күшті жағы болып табылады. Бұл ретте Норвегия қаржы министрлігі қордың инвестициялық стратегиясы қордың жауапты инвестор ретіндегі рөлін ескере отырып, этикалық және моралдық нормаларға негізделуі тиіс екенін атап көрсетеді (Folketrygdfondet: government bond fund website, 2019). 
Инвестицияларды басқару арқылы портфельдерді әртараптандырудың маңыздылығы атап көрсетілген. Қазіргі уақытта инвестициялық портфельді басқаруда ұжымдық инвестициялау түріндегі қолда бар қаражатты инвестициялау әдісі неғұрлым танымал болуда. Бұл жеке инвесторлардың көптеген санының ортақ мүдделеріне негізделген әдіс, оларда бар қаражатты барынша тиімді бағалау.

Ұжымдық инвестициялар үшін негізгі бастапқы мақсат портфельді әртараптандыру жолымен инвесторлардың тәуекелдерін азайту болып табылады. Ұжымдық инвестициялаудың артықшылықтары тәуекелдерді неғұрлым тиімді әртараптандыру, жинақтарды кәсіби басқару, ұсақ инвесторлар үшін инвестициялық мүмкіндіктердің болуы және оларды кеңейту болып табылады (Erika, 2018: 168).

Сондай-ақ, құралдардың үлкен таңдауы, жоғары өтімділік, төмен шығындар, банктік депозиттермен салыстырғанда ақпараттық және салықтық артықшылықтардың жеткіліксіздігі бар. Бұл өз қаражатын осында салуға көбірек инвесторларды тартады.

Ұжымдық инвестицияларды жүзеге асырумен қатар портфельдік теориялар және оны осы салада қолдану бірінші орынға шықты. Портфельдік теорияның принципі - инвестициялық кәсіпорындар мен олардың қорларының, инвестициялық пай қорлары мен зейнетақы қорларының мақсаттарына қол жеткізу үшін пайдаланылатын әртараптандыру, сондай-ақ портфельді құруды, басқаруды және клиенттерге барынша оң әсер етуді қамтамасыз етеді.

Инвестициялау және инвестициялық пай қорлары арқылы ұжымдық инвестициялаудың негізгі артықшылықтары мынадай фактілерде көрсетіледі:

Ауқымның әсерінен үнемдеуге алып келеді;

Кәсіби басқаруды сақтайды;

Барлық елдерде ұжымдық инвестицияларды мемлекеттік қадағалау мен бақылаудың мәні болып табылады;

Құралдарды әртүрлі бағалы қағаздардың көптеген түрлеріне салу және оларды әртараптандыру арқылы инвестордың тәуекелін едәуір төмендетеді.

Ұжымдық инвестициялардың ерекше артықшылығы - олар инвестициялық стратегиялардың кең спектрін ұсынады. Кейіннен әрбір инвестор қор түрін таңдай алады, ол оның тәуекел және уақыт пен инвестициялық артықшылықтарына сәйкес келеді. Инвесторлар үшін ұжымдық инвестициялардың тиімсіз аспектілері:
Инвестор төлеуге жататын мүшелік жарналар;

Қорды басқару үшін әкімшілік алымдар;

Қорлардың акциялары мен пайларына бағалардың құбылмалылығы, кірістілікке әсер ететін ауыткулар;

Сақтандырудың болмауы.

Марковиц ресурстар мен капиталдың оңтайлы бөлінуін сипаттады, оның мақсаты инвестициялық қорлардан барынша жоғары қайтарымды қамтамасыз ету болып табылды. Алайда, тәуекелді төмендететін портфельдің әртараптандырылуын анықтау аса маңызды болды. Портфельді әртараптандыру тұжырымдамасы портфельдің барлық теориясының негізінде жатыр, сондай-ақ селективті үлгі ретінде белгілі. Марковицтің селективті моделі келесі ақпаратқа негізделген:

- барлық инвесторлар бірдей ұзақ мерзімде инвестиция салады;

- күтілетін кірістілік және күтілетін тәуекел инвесторлар іздеген инвестициялық шешімдердің бөлігі болып табылады;

- стандартты ауытқу;

- күтілетін нәтиже инвестициялық шешімдердің негізі болып табылады;

- капиталдың жасалған нарықтарының болуы тиімді нарықтардың теориясымен келісіледі.

Инвестор тәуекел дәрежесін және өз инвестицияларының күтілетін табыстылығын бағалай алады (Khaira, 2017).

Іріктемелі модельдің алғышарттары Марковицтің тұжырымдамасында: Егер инвестор жалпы портфелдік тәуекелді төмендеткісі келсе, ол өзара мінсіз корреляцияланатын активтерді біріктіруі тиіс. Инвестициялық құралдардың кірістілігін, тәуекелін және өтімділігін есептеу және есепке алу күрделі мәселе болып табылмайды. Шын мәнінде, инвестор тек бір инвестициялық құралға ие емес, бірақ әдетте өзінің еркін қаражатын бірнеше түрлі құралға - портфельге инвестициялайды.

Портфель кірістілігін өлшеу үшін кіріс деректерін ажырату, сондай-ақ жеке құралдардың кірістілігін өлшеу қажет. Пайданың күтілетін мәні немесе орташа нормасы сол кезеңдердегі геометриялық немесе арифметикалық орташа пайданы пайдалана отырып, оңай есептелуі мүмкін. Егер барлық қайтарымдар (return) ықтималдылықпен болса, онда барлық шығыстар олардың санына бөлінеді (қарапайым орташа арифметикалық):

$$
R 1=\sum_{j=1}^{N} \frac{R i j}{N}
$$


Егер барлық қайтарымдар ықтималдықпен болмаса, онда әрбір қайтарым Ріј ықтималдығы берілуі тиіс, яғни i - активке j - қайтару ықтималдығы (bajus, 2011):

$$
R 1=\sum_{j=1}^{N} P i j R i j
$$

Bajus e (Ri) кірістіліктің күтілетін мәнінің келесі сипаттамаларын анықтайды: - екі кірістілік (шығыс) сомасының күтілетін мәні әрбір кірістіліктің күтілетін мәндерінің сомасына тең, осылайша:

$$
E(R 1 j+R 2 j)=R 1+R 2
$$

С константасының күтілетін мәні кірістілік ставкасы тұрақты көбейтіледі.

Портфель тәуекелі және оның ставкасы

Тәуекел инвестициялар нәтижесінің белгісіздігімен байланысты және пайданың нақты нормасы болжанғаннан өзгеше болады. Бұл пайызда қаржылық талдаушылар көрсеткен кірістілік айналасындағы стандартты ауытқудың вариациясы. Осылайша, тәуекелдерді сандық бағалау кезінде сарапшылар өз көзқарастары мен нанымсенімдеріне сүйеніп қана қоймай, статистикалық есептерге сүйеніп отырады. Тәуекелді өлшеу үшін екі есеп қолданылады: - ex post - дисперсия тәуекелін есептеу және стандартты ауытқу ретінде есептеледі:

$$
\delta^{2}=\frac{\sum_{t}^{T}=1(V-V t)}{T}
$$

Ex ante тәуекел ставкасын есептеу ex-post есебінен күтілетін (болжамды) мәндермен ерекшеленеді. Бұл есептеу бағалау ықтималдығын есептейді:

$$
\delta^{2} \text { ante }=\frac{1}{T-1} \sum_{t=1}^{T}[E(v)-E(v-1)]^{2}
$$

\section{Ковариация және корреляция}

Портфельдегі жеке құралдардың кірістілігі арасындағы корреляция, ковариациямен өлшенуі мүмкін. Бұл құралдардың табыстылығы мен олардың қозғалыс бағыты арасындағы сызықтық тәуелділік туралы ақпарат беретін статистикалық шара. Ковариацияның оң мәні екі құралдың табыстылық қозғалысы арасындағы оң байланыс туралы айтады. Керісінше кірістілік қарама-қарсы бағытта қозғалатын теріс ковариация. Нөлдік ковариация мәні екі зерттелетін құралдардың арасында ешқандай байланыс жоқ екенін көрсетеді (Kliestik, 2017: 78-80).
Егер бізде кезең ішінде екі құралдың түрлі тарихи ставкалары туралы тарихи орташа кірістілік нормасы және ақпарат жоқ болса, онда тарихи ex post ковариация ретінде есептеледі:

$$
\operatorname{Cov}_{A . B}=\frac{1}{T} \sum_{t=1}^{T}\left(r_{A T}-r_{A A}\right) *\left(r_{B T}-r_{B B}\right)(6)
$$

мұндағы,

$\operatorname{Cov}_{\mathrm{A}, \mathrm{B}}-\mathrm{A}$ және В құралдары бойынша тарихи пайыздық ставкалардың қозғалысымен байланысты тарихи ковариация;

$\mathrm{r}_{\mathrm{AA}}-\mathrm{a}$ құралы кірістілігінің орташа тарихи нормасы;

$\mathrm{r}_{\text {BA }}$ - В құралы орташа тарихи табыс;

$\mathrm{r}_{\mathrm{Ai}}$ - есепті кезеңдегі А құралының жеке тарихи табыстылығы;

$\mathrm{r}_{\mathrm{Bi}}$ - есепті кезеңде В құралының жеке тарихи кірістілігі;

T - зерттеу кезеңі ішіндегі жылдар саны.

Егер есептеу кезінде құралдардың жалпы күтілетін табыстылығы пайдаланылса, онда әрбір жеке кірістілік үшін күтілетін табыстылық сандық түрде анықталады, ал онымен байланысты ықтималдық қатынасы мынадай түрде есептелген ковариацияны білдіреді:

$E\left(\operatorname{cov}_{A \cdot B}\right)=\sum_{i=1}^{l} P_{i}\left[E\left(r_{A i}\right)-E\left(r_{A}\right)\right] *\left[E\left(r_{B i}\right)-E\left(r_{B}\right)\right](7)$

мұндағы,

E $\left(\operatorname{cov}_{\mathrm{A}, \mathrm{B}}\right)-\mathrm{A}, \mathrm{B}$ құралының күтілетін кірістілік нормасының қозғалысы арасындағы күтілетін ковариация;

E $\left(\mathrm{r}_{\mathrm{A}}\right)$ - а құралының жалпы күтілетін кірістілігі;

E $\left(\mathrm{r}_{\mathrm{B}}\right)$ - В құралының жалпы күтілетін кірістілігі;

$\mathrm{E}\left(\mathrm{r}_{\mathrm{Ai}}\right)$ - жеке масақ өнімділігіне сәйкес келетін әрбір күтілетін а құралы табыстылығы;

$\mathrm{E}\left(\mathrm{r}_{\mathrm{Bi}}\right)$ - жеке өнімділікке сәйкес әрбір күтілетін В құралы бойынша табыстылық деңгейі;

$\mathrm{P}_{\mathrm{i}}$ - A және b құралдары бойынша әрбір күтілетін кірістілік ставкасына сәйкес келетін ықтималдық қатынасы;

I - кірістілік нұсқаларының саны.

Корреляция коэффициентін инвестор, оған жоспарланған түзетулер арасындағы өзара байланысдәрежесі,күші туралы ақпаратқажетболғанда пайдаланады. Корреляция коэффициенті екі айнымалы арасындағы сызықтық тәуелділіктің статистикалық өлшемі болып табылады. Ковариациямен салыстырғанда бұл күші мен дәрежесі туралы ақпарат бере алатын корреляция коэффициентінің өлшемі. Коэффициентін есептеу корреляция жөн есеппен ковариации. Бұл 
ковариацияның бақыланатын айнымалы кірістіліктің стандартты ауытқуына бөлінуі. Бұл екі коэффициент тек өзінің түсіндіруімен және мәнерлі нәтижеге қабілеттілігімен ерекшеленеді. Корреляция коэффициенті:

$$
P_{A . B}=\frac{\operatorname{cov}_{A . B}}{\delta_{A} \delta_{B}}
$$

мұндағы,

$P_{A . B}-$ А және В құралдарының кірістілік қозғалысы арасындағы корреляция коэффициенті, ex post немесе ex ante;

$\operatorname{cov}_{\mathrm{A}, \mathrm{B}}-\mathrm{A}$ және В құралдарының арасындағы кірістілік қозғалысының ковариациясы ex post немесе ex ante;

$\sigma_{\mathrm{A}}-$ стандартты ауытқу ex post немесе ex ante, А құралының жалпы тәуекел ставкасы;

$\sigma_{\mathrm{B}}-$ стандартты ауытқу ex post немесе ex ante, B құралының жалпы тәуекел ставкасы.

Марковицтің тұжырымдарына сәйкес, тиісті портфельдің принципі тәуекелді әртараптандыру болып табылады және кірістілігі оң корреляцияланатын, синхронды жылжитын және кірістілігі тұтастай портфель бойынша кірістілікті ауыстыратын портфель құралдарын таңдау қажет.

Бұл синхронды жағдайда портфель кірістілігі төмендеген кезде, олардың құралдарының кірістілігі де төмендейді дегенді білдіреді.

Бұл мақалада біз қарастыратын келесі коэффициент - Шарп коэффициенті. Мәселен, инвестициялық қордың кірістілігі мен тәуекелін бағалау үшін Шарп коэффициентін қолдануды зерттейміз. Шарп коэффициенті-инвестициялық портфельді немесе инвестициялық пай қорын (ИПҚ) басқарудың тиімділігі мен нәтижелілігін бағалауға мүмкіндік беретін көрсеткіш. Бұл коэффициент 1966 жылы Шарппен әзірленген.

Шарп коэффициенті төмендегілерді бағалау үшін қолданылады:

- инвестициялық пай қорларын басқару сапасы;

- қор нарығындағы белсенді сауда стратегияларының нәтижелілігі;

- инвесторлардың инвестициялық портфельдерін қалыптастыру тиімділігі.

Шарп коэффициенті кірістіліктің - инвестициялық қордың тәуекелінің салыстырмалы көрсеткіші болып табылады және артық кірістілік деңгейі инвестициялар тәуекелінің деңгейінен қанша есе жоғары екенін көрсетеді. Шарп коэффициентін есептеу формуласы төменде берілген:

$$
\text { Sharp ratio }=\frac{r p-r f}{\sigma p},
$$

мұндағы,

rp - ИПК-ның (инвестициялық портфельдің) орташа кірістілігі);

rf - тәуекелсіз активтің орташа кірістілігі;

бр - ИПҚ активтері кірістілігінің стандартты ауытқуы (тәуекел).

Мысалы, инвестициялық пай қорының немесе инвестициялық портфельдің орташа кірістілігі мен тәуекелсіз активтің орташа кірістілігі арасындағы айырманы ИПҚ активтері кірістілігінің стандартты ауытқуына, яғни оның тәуекеліне бөлу қажет. Инвестор алған артық кірістілікті бағалау үшін ол мүлдем сенімді активтерге салған кезде алуы мүмкін ең аз ықтимал кірістілікті есептеу қажет. Тәуекелсіз активтің кірістілігін бағалаудың бірнеше жолы бар. Бұл, мысалы, неғұрлым ірі және сенімді банктердің банктік салымының кірістілігі; бұл тәуекелсіз мемлекеттік бағалы қағаздардың кірістілігі және тағы басқалар (Зыбин, 2014: 116-120).

Шарп коэффициентібойыншаинвестициялық пай қорының бағасын қарастырайық: егер Шарп коэффициенті бірліктен асса, бұл басқару стратегиясы тиімді, яғни портфельдің кірістілігі тәуекелсіз актив бойынша кірістен асып түседі және тәуекел деңгейінен асып түседі дегенді білдіреді. Егер Шарп коэффициенті нөлден бірлікке дейін болса, онда басқару стратегиясы тиімді емес. Бұл жағдайда портфель тәуекелі оның кірістілігінен асып түседі, портфелді қайта құрылымдау және әртараптандыру қажет. Егер Шарп коэффициенті теріс болса, басқару стратегиясы тиімсіз. Инвестициялық портфель бойынша кірістілік тәуекелсіз актив бойынша кірістілікке қарағанда төмен. Сондықтан тәуекелсіз активке салу орынды. Егер бір ИПҚ Шарп коэффициентінің мәні басқа ИПК Шарп коэффициентінің мәнінен жоғары болса, онда қор неғұрлым қолайлы және осы көрсеткіштің ең үлкен мәні болып табылады. Осылайша, қарастырылатын көрсеткішті бағалау инвестициялық тартымды қорларды, портфельдерді немесе салу стратегиясын таңдауға мүмкіндік береді (Палагина, 2015: 200-208).

Біз қарастыратын келесі коэффициент Сортино коэффициенті.

Ол Шарп коэффициентіне ұқсас, портфельмен байланысты тәуекел деңгейін өлшеу үшін пайдаланылады. Сортино коэффициенті жоғары болған сайын, ілеспе тәуекелге қатысты портфель көрсеткіштері де жақсы болады. Көбінесе ол табыстың белгілі бір деңгейіне жету үшін әртүрлі портфельдер бойынша тәуекел көлемін салыстыру үшін пайдаланылады. 
Сортино коэффициентінің қаншалықты жоғары немесе төмен екенін анықтау үшін оны қорларды, индекстерді немесе санаттарды бірбірімен салыстыру контексінде қарау қажет. Сортино коэффициенті портфель кірістілігінің көздері - ойластырылған инвестициялық шешімдер немесе артық тәуекел болып табылатынын көрсетеді. Сонымен, Сортино коэффициенті Шарп коэффициентіне ұқсас болғанмен есептеудің басқа әдісін пайдаланады. Стандартты ауытқудың орнына теріс жаққа ауытқу, яғни «төмен ауытқу» қолданылады (Kollar, 2014: 43-46).

Бұл стандартты ауытқу құбылмалылықтың абсолюттік өлшемі болып табылады. Осы параметрді пайдалана отырып, Сортино коэффициенті ауыткуды жоғары есепке алмай, тек теріс құбылмалылықтың әсерін көрсетеді, яғни «артық» пайда (Пономарева, 2014: 80-83).

Есептеу үшін инвесторға инвестордың талаптарын қанағаттандыратын табыстың ең төменгі қолайлы нормасын көрсету талап етіледі. Пайданың қолайлы нормасынан тыс кез келген пайда Сортино коэффициентін есептеу кезінде пайдаланылмайды.

$$
S P=\frac{r p-r f}{\sigma p},
$$

мұндағы,

rp - ИПҚ-ның (инвестициялық портфельдің) орташа кірістілігі;

rf - тәуекелсіз активтің орташа кірістілігі;

$\sigma p$ - ИПҚ-ның (инвестициялық портфельдің) активтері кірістілігінің теріс жағына ауытқуы. Есептеу алгоритмі бойынша, ең алдымен тәуе- келсіз пайыздық ставканы портфель кірістілігінен шегеру қажет. Содан кейін нәтижені портфель кірістілігінің теріс жағына ауыткуына бөлу қажет. Тек түрлі портфельдердің Сортино коэффициенттерін салыстыра отырып, тәуекелге түзету арқылы пайда туралы түсінік алуға болады. Басқа көрсеткіштермен бірге Сортино коэффициенті инвесторларға қаржылық қажеттіліктерге сай келетін және тәуекел шекаралары туралы ұсыныстарға сәйкес келетін стратегияны әзірлеуге көмектеседі (Царук, 2015: 192-195).

Тағы бір коэффициентті қарастырайық: 2002 жылы Keating және Chadwick ғалымдары Омега атауын алған инвестициялық портфельдерді басқарудың тиімділігін бағалаудың жаңа көрсеткішін ұсынды. Бұл көрсеткіш портфельді басқару тиімділігін салыстыруға ғана емес, сондай-ақ инвестициялық пай қорының қызметін, сауда стратегиясын, басқарушының қызметін және т.б. бағалауға мүмкіндік береді.

3-суретте портфель кірістілігін бөлу функциясы көрсетілген, G саласы X белгіленген деңгейден асатын кірістілікті алу мүмкіндігі болып табылады. L аймағы - бұл жеңіліс аймағы.

Омега коэффициентін есептеу формуласы:

$$
\omega=G / L
$$

мұндағы,

$\omega$ - Омега коэффициенті;

$\mathrm{G}$ - белгіленген х деңгейінен асатын кірістілікті алу ықтималдығы;

$\mathrm{L}$ - ұтылу аймағы.

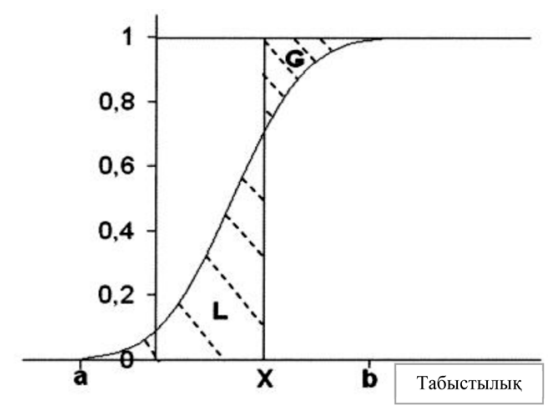

3-сурет - Портфель кірістілігін бөлу функциясы

Кірістіліктің бірдей шегі кезінде портфельдік басқарушы Омега коэффициентінің үлкен мәні бар портфельді таңдауға тиіс (Волков, 2014: 9-14). Көрсеткіш немесе коэффициент, Омега Шарп мен Сортино көрсеткіштерінен гөрі тиімділіктің кешенді көрсеткіші болып табылады. Осы коэффициенттің артықшылықтарының бірі оның көмегімен әртүрлі портфельдердің кірістілігін бөлудің қалыпты заңымен де, одан да өзгеше нормалармен де салыстыруға болады. 
Омега функциясы арқылы әр түрлі активтерді немесе портфельдерді салыстыруға болады. Омега активтің кірістілігін бөлуге баламалы болғандықтан, оның негізінде инвестор бір активті немесе портфельді басқасына артықшылық ету туралы саналы шешім қабылдай алады. Бұл кірістіліктің әртүрлі деңгейлері үшін ықтимал тәуекелді ескере отырып, активтердің кірістілік серпіні өзгеретіндігімен байланысты. Омега коэффициенті Сортино коэффициенті сияқты инвестор белгілеген кірістіліктің ең аз рұқсат етілген деңгейін пайдаланады (Лятин, 2014: 59-61).

Қорыта келгенде, инвестициялық пай қорларының кірістілігі мен тәуекелінің және басқару тиімділігінің сипаттамалары болып табылатын басқа да коэффициенттерге шолу жүргізейік.

Бета коэффициенті - коэффициенттің мәні 0-ге жақынырақ болған сайын, соғұрлым табыс нарықтық кірістілікке ұмтылады. Теріс мән нарықтың өсуі кезінде бұл ИПҚ-ның табыстылығы теріс және керісінше болатынын көрсетеді (Nick, 2012: 480).

Альфа коэффициенті - егер осы коэффициенттің мәні 0-ден артық болса, бұл қор басқарушысы өзіне алған тәуекелдің ақталғанын білдіреді, теріс мәндерде - керісінше. Егер портфельдің орташа кірістілігі эталондық құралдың орташа кірістілігінен асып түссе, онда портфельді басқару тиімді болды, бұл жағдайда альфа коэффициенті оң болады; егер эталон бағаланатын портфельге қарағанда үздік нәтижелерді көрсеткен болса, альфа теріс болады.

VaR коэффициенті немесе Value at Risk тәуекел көрсеткіші. VaR - бұл сенімді аралық деңгейінің мүмкіндігінен аспайтын шығындар шамасы. VaR әдісі шын мәнінде стандартты ауытқуды есептеуге негізделген тәуекелді өлшеудің классикалық әдісінің дамуы болып табылады. VaR көрсеткішіне сүйене отырып, біз келесі айда шығындар $\mathrm{VaR}$ көрсеткішінен аспайды деген қорытынды жасай аламыз. Егер $\mathrm{VaR}$ оң болса, онда бұл қор пайының құны кем дегенде осы сомаға өседі. Құбылмалылық - бұл өзгергіштіктің сипаттамасы: құбылмалылық жоғары болған сайын, нәтижелерін де болжау қиынға соғады.

R2 коэффициенті - көрсеткіш 100\%-ға жақын болған сайын, қор индекстің қозғалысын қайталайды (Gaudecker, 2015).

\section{Қорытынды}

Қаржы нарығына инвестициялау қаржы саласындағы зерттеуде өте маңызды орын ала- ды. Портфельдік инвестициялау теориялары бағалы қағаздар портфелін қалыптастыруға және басқаруға мұқият іріктеумен қарау керек. Теориядан басқа, белгілі инвесторлар да өзінің басқару принциптерін ұсынады. У. Баффет пен Р. Далио инвестициялау принциптері өте тиімді, қарапайым және бұл портфельдерді кез келген инвестор құра алады. Қарастырылған коэффициенттердің әрқайсысы портфель туралы өз ақпаратын алып, оларды кешенді түрде қарастыру қажет. Әрине, пай қорын таңдау қарастырылған коэффициенттерге ғана емес, инвестордың жеке мақсаттарына да байланысты.

Бұл ретте мыналар ескеріледі: инвестициялаудың болжамды сомасы; инвестициялаудың болжамды мерзімі; инвестор баруға дайын тәуекел; инвестордың күтілетін кірісі. Барлық осы параметрлер өзара байланысты. Алайда, дұрыс шешім табу қиын. Басқарушы компанияны таңдауда әрбір компанияға белгілі бір сенімділік дәрежесін беретін рейтингтік агенттіктер көмектесе алады. Пай қорын таңдау кезінде белгілі бір кезеңдегі пай құнының серпіні және пай қорлары жұмысының сапасы мен тұрақтылығының көрсеткіштеріне да назар аудару маңызды. Осылайша, қандай да бір қорға артықшылық бере отырып, таңдалған қордың қызметін жан-жақты бағалаған, таза активтердің құнын, пайдың құнын, сондай-ақ сату/сатып алу балансын әр түрлі кезеңдердің динамикасында ғана емес, сондай-ақ сол түрдегі басқа пай қорларының ұқсас көрсеткіштерімен де салыстырған жөн. Әрине, портфельді басқару тиімділігін сипаттайтын коэффициенттерді зерттеу керек.

Алайда, нарықтың дамуымен қағидаттар өзгеруі мүмкін және инвестор нарықтағы жаңалықтарды бақылап отыруы тиіс. Нарық орнында тұрмайды, ол қарқынды дамып келеді, барлық жаңа құралдар пайда болады. Сонымен қатар, табысты инвесторлардың тексерілген ережелері бар, олардың көмегімен салым тәуекелін төмендету ғана емес, сонымен қатар жоғары кірістілік алу да мүмкін.

Инвесторға арналған ұсыныстар ретінде тиімді инвестициялық портфельді қалыптастыру коэффициенттері мен инвестициялық қызметті жүзеге асырудағы мәселелерді шешуге көмектеседі.

Инвестициялық портфельді қалыптастыру кезінде көптеген қағидалар мен ережелер бар. Сонымен қатар, бұл қағидалар кейбір жағдайларда қайшы келеді. Сондықтан да инвестициялық портфельді қалыптастырудың барлық 
қағидаларын зерттеп, инвестициялаудың мақсаты мен ерекшеліктерін ескеру керек. Әсіресе инвестициялық порфтельді әртараптандыру, альфа, бета коэффициентіне және тәуекелді анықтау коэффицинттеріне көңіл аудару керек.

Зерттеуді жүргізудің құндылығы ретінде инвестициялық портфельді қалыптастыру мен оның қызметінің тиімділігін бағалау алынды. Сонымен қатар порфельдік инвестициялаудың отандық пен шетелдік экономистердің ойпікірлері талқыланып, біздің мемлекетіміздегі ерекшеліктерді ескере отырып инвестициялаудың ережелері талқыланды. Инвестициялық портфеліне қатысты барлық факторлар мен көрсеткіштер жүйесі талқыланды.

Жұмыс нәтижесінің практикалық маңыздылығы ретінде зерттеудегі негізгі қорытындылар бағалы қағаздардың трейдингін және инвестициялау жүргізуде қолдануға болады.

\section{Әдебиеттер}

Buc D., Kliestik T. Aspects of statistics in terms of financial modelling and risk / Proceeding of the 7 th International Days of Statistics and Economics. - Prague. - 2013, pp. 215-224.

Burrough P.A. Fuzzy mathematical methods for soil survey and land evaluation // J. soil sci. - 2010, pp. 477-492.

Spuchlyakova E., Michalikova K.F., Misankova M. Risk of the Collective Investment and Investment Portfolio // Procedia Economics and Finance. - 2018. - vol. 26, pp. 167-173.

Gaudecker H.M.V. How does household portfolio diversification vary with financial literacy and financial advice? // Journal of Finance. - 2015. - vol. 70(2), pp. 489-507.

Khan M.T.I., Tan S.H., Chong L.L. Gender differences in preferences for firm characteristics across different groups of investors. -2016

Fachrudin K.A., Fachrudin H.T. The Study of Investment Portfolio Management and Sustainability of Property and Real Estate Companies in Indonesia Stock Exchange / 2nd Global Conference on Business and Social Science, GCBSS. - Bali, Indonesia. 2017.

Kollar B., Cisko S. Credit risk quantification with the use of CreditRisk / Proceedings of ICMEBIS 2014 International Conference on Management, Education, Business, and Information Science. - Shanghai, China: EDU Gait Press, Canada. - 2014, pp. $43-46$.

Kliestik T. Risk models based on capital structure of a company // Scientific Journal Forum statisticum Slovacum. - 2017. - vol. 9, № 6, pp. 78-83.

Nick G. Providing a multi-objective model in the fuzzy portfolio selection. Master Thesis management. Azad University of Qazvin // Qualitative Research in Financial Markets. - 2012. - vol. 8(1), pp. 2-15.

Tussayeva A. Principles of stock portfolio management for individual investor // International Journal of Advanced. - 2015. vol.5. - № 4, C. 36-42

Folketrygdfondet: government bond fund website. - 2019, https://www.folketrygdfondet.no/the-government-bond-fund/category402.html

Волков И.В. Некоторые подходы в управлении инвестициями в АПК // Вестник НГИЭИ. - 2014. - №5(36), С. 9-14.

Зыбин А.А. Понятие, типы и цели формирования инвестиционного портфеля // Научно-методический электронный журнал «Концепт». - 2014. - № 1, С. 116-120, http://e-koncept.ru/2014/14024.htm.

Лятин А.В., Ерилин С.А. К вопросу о проблематике управления кредитными рисками // Азимут научных исследований: экономика и управление. - 2014. - № 3, С. 59-61.

Материалы for Trader.ru. Индексы фондового рынка, S\&P500/fortrader.ru

Нечаев К.Ю. Развитие теории портфельного инвестирования / Экономический портал http://institutions.com

Палагина Т.В. Построение прогноза объемов инвестиций в основной капитал в промышленности Кыргызской республики // Актуальные проблемы экономики и права. - 2015. - №1(33), С. 200-208.

Паук М.И. Эффективность влияния иностранных инвестиций на социально-экономическое развитие региона // Азимут научных исследований: экономика и управление. - 2014. - № 3, С. 72-76.

Пономарева И.В. К вопросу о механизме привлечения инвестиций во внешнеторговые операции // Азимут научных исследований: экономика и управление. - 2014. - № 3, С. 80-83.

Роббинс Э. Деньги. Мастер игры: 7 простых шагов к финансовой свободе. - Минск. - 2015, С. 330-363.

Царук В.Ю. Мировые тенденции реализации экономического роста с помощью инвестиций // Балтийский гуманитарный журнал. - 2015. - №1(10), С. 192-195.

\section{References}

Buc D., Kliestik T. (2013) Aspects of statistics in terms of financial modelling and risk. Proceeding of the 7th International Days of Statistics and Economics, Prague, pp. 215-224.

Burrough P.A. (2010) Fuzzy mathematical methods for soil survey and land evaluation. J. soil sci., vol. 40, pp. 477-492. 
Fachrudin K.A., Fachrudin H.T. (2017) The Study of Investment Portfolio Management and Sustainability of Property and Real Estate Companies in Indonesia Stock Exchange. 2nd Global Conference on Business and Social Science, GCBSS, Bali, Indonesia.

Folketrygdfondet government bond fund website (2019) https://www.folketrygdfondet.no/the-government-bond-fund/category402.html

Gaudecker H.M.V. (2015) How does household portfolio diversification vary with financial literacy and financial advice? Journal of Finance, vol. 70(2), pp. 489-507.

Khan M.T.I., Tan S.H., Chong L.L. (2016) Gender differences in preferences for firm characteristics across different groups of investors.

Kliestik T. (2017) Risk models based on capital structure of a company, Scientific Journal Forum statisticum Slovacum, vol. 9 , no. 6, pp. 78-83.

Kollar B., Cisko S. (2014) Credit risk quantification with the use of CreditRisk. Proceedings of ICMEBIS 2014 International Conference on Management, Education, Business, and Information Science, Shanghai, China, EDU Gait Press, Canada, pp. 43-46.

Liatin A.V., Erilin S.A. (2014) K voprosy o problematike upravleniia kreditnymi riskami [On the issue of credit risk management]. Azimut nauchnyh issledovanii: ekonomika i upravlenie, vol. 3, pp. 59-61.

Materialy for Trader.ru. Indeksy fondovogo rynka [Stock market index], S\&P 500/fortrader.ru/

Nechaev K.Yu. (2014) Razvitie teorii portfelnogo investirovaniia [The development of the theory of portfolio investment]. Ekonomicheskii portal http://institutions.com

Nick G. (2012) Providing a multi-objective model in the fuzzy portfolio selection. Master Thesis management. Azad University of Qazvin. Qualitative Research in Financial Markets, vol. 8(1), pp. 2-15.

Palagina T.V. (2015) Postroenie prognoza obemov investitsii v osnovnoi kapital v promyshlennosti Kyrgyzskoi respubliki [Forecasting the volume of investments in fixed assets in the industry of the Kyrgyz Republic]. Aktualnye problemy ekonomiki i prava, vol. 1(33), pp. 200-208.

Pauk M.I. (2014) Effektivnost' vliianiia inostrannyh investitsii na sotsialno-ekonomicheskoe razvitie regiona [Effectiveness of foreign investments influence on social and economic development of the region]. Azimut nauchnyh issledovanii: ekonomika i upravlenie, vol. 3, pp. 72-76.

Ponomareva I.V. (2014) K voprosu o mehanizme privlecheniia investitsii vo vneshnetorgovye operatsii [On the mechanism of attracting investments in foreign trade operations]. Azimut nauchnyh issledovanii: ekonomika i upravlenie, vol. 3, pp. 80-83.

Robbins E. (2015) Dengi. Master igry: 7 prostyh shagov k finansovoi svobode [Master the game: 7 simple steps to financial freedom]. Minsk, pp. 330-363.

Spuchlyakova E., Michalikova K.F., Misankova M. (2018) Risk of the Collective Investment and Investment Portfolio. Procedia Economics and Finance, vol. 26, pp. 167-173.

Tsaruk V.Yu. (2015) Mirovye tendentsii realizatsii ekonomicheskogo rosta s pomoiu investitsii [Global trends in the implementation of economic growth through investment]. Baltiiskii gumanitarnyi jurnal, vol. 1(10), pp. 192-195.

Tussayeva A. (2015) Principles of stock portfolio management for individual investor. International Journal of Advanced, vol. 5, no. 4, pp. 36-42.

Volkov I.V. (2014) Nekotorye podhody v upravlenii investitsiiami v APK [Some approaches in the management of investment in the agricultural sector ]. Vestnik NGIEI, vol. 5(36), pp. 9-14.

Zybin A.A. (2014) Poniatie, tipy i tseli formirovaniia investitsionnogo portfelia [Concept, types and goals of investment portfolio formation]. Naýchno-metodicheskii elektronnyi jurnal «Kontsept», vol. 1, pp. 116-120, http://e-koncept.ru/2014/14024.htm. 